\title{
Negara Kesejahteraan dan Maqasid Syariah: Analisis Pemikiran Jamaluddin Athiyyah
}

\author{
Syamsuri \& Dadang Irsyamuddin \\ Program Studi Ekonomi Islami, Fakultas Ekonomi dan Manajemen, \\ Universitas Darussalam Gontor \\ Email: syamsuri@unida.gontor.id
}

\begin{abstract}
The discourse about the Welfare State is interesting. This article aims to conduct in-depth analysis related to the concept of the welfare state and its relation to maqasid sharia according to Jamaluddin Athiyyah. The method used in this study is qualitative with a literature approach, namely conducting a study of the literature surrounding the welfare state and the Maqasid sharia. The conclusion of this study is that Athiyyah provides an overview of the division of tasks of the government in ensuring the welfare of its people into four dimensions, namely: individuals, families, society and humanity. Furthermore it was stated that the three basic principles of maqasid sharia to create prosperity would not be fulfilled but rather with the active role of the State.
\end{abstract}

Keywords: Welfare State, Maqasid Syariah, Family, Humanity.

\begin{abstract}
ABSTRAK
Diskursus perihal Negara Kesejahteraan masih saja menarik untuk dikaji. Artikel ini bertujuan untuk melakukan analisis mendalam terkait dengan konsep negara kesejahteraan dan kaitannya dengan maqasid syariah menurut Jamaluddin Athiyyah. Metode yang digunakan dalam penelitian ini ada kualitatif dengan pendekatan pustaka, yaitu melakukan kajian terhadap literatur seputar Negara kesejahteraan dan maqasid syariah. Kesimpulan dari penelitian ini adalah bahwa Athiyyah memberikan gambaran pembagian tugas pemerintah dalam menjamin kesejahteraan rakyatnya ke dalam empat dimensi yaitu: individu, keluarga, masyarakat dan kemanusiaan. Lebih
\end{abstract}


lanjut dinyatakan bahwa tiga prinsip dasar maqasid syariah untuk menciptakan kesejahteraan tidak akan bisa terpenuhi melainkan dengan peran aktif Negara.

Kata Kunci: Negara Kesejahteraan, Maqasid Syariah, Keluarga, Kemanusiaan.

\section{Pendahuluan}

Kesejahteraan merupakan permasalahan yang telah menjadi perhatian utama bagi seluruh negara di dunia, negara dan lembaga internasional berupaya menyepakati ukuran tertentu untuk mengukur tingkat kesejahteraan sehingga PBB dengan berupaya merumuskan variabel kesejahteraan yang berlaku secara universal, yang sering disebut Human Development Index (http://www. http://hdr.undp.org/en/). Konsep itu kian dilengkapi dengan perhitungan index lain yang memiliki cakupan lebih luas dalam The Legatum Prosperity Index dengan indikator 1) Kualitas Ekonomi, 2) Lingkungan Bisnis, 3) Pemerintahan, 4) Pendidikan, 5) Kesehatan, Keamanan, 6) Kebebasan individu, 7) Modal sosial, dan 8) Sumber daya alam (The Legatum Institute Foundation, 2016: 5-6). Namun berdasarkan data dari World Health Organization (WHO) (http://www.who.int/about/en/), presentase bunuh diri di New Zealand cukup tinggi yaitu sebesar 17,3\% dari 100.000 jiwa, jika dibandingkan dengan Indonesia yang tingkat kesejahteraannya menempati posisi ke 139 dalam The Legatum Prosperity Index justru presentase bunuh dirinya cukup rendah dari Norwegia yaitu sebesar 3,0\% pada 2016 dari 100.000 jiwa (http://www.who.in). Hal ini tidak lain disebabkan oleh ketimpangan pemahaman tentang kesejahteraan itu sendiri yang hanya diambil dari segi fisik semata.

Kesejahteraan yang diimpikan oleh tiap individu tersebut tidak dapat direalisasikan dengan kehendak dan kekuatan personal. Mereka membutuhkan wadah dan kumpulan kekuatan yang lebih besar melalui negara dan pemerintah. Negara harus mewujudkan kesejahteraan semua penduduknya dengan bantuan dengan kekuatan dan kekuasaan yang mereka miliki sehingga menghindari ketimpangan sosial (Kansil, 2001: 133). Tuntutan tersebut berbuah munculnya konsep kenegaraan baru yang bernama welfare state yang sering dianggap sebagai 'penawar racun' bagi kapitalisme dari dampak negatif ekonomi pasar bebas.

Islam mengajarkan bahwa negara harus berusaha merealisasikam nilai spritual dalam organisasi manusiawi. Dengan demikian, ia adalah instrumen untuk mewujudkan tujuan kesejahteraan spiritual dan material warganya secara bersamaan. Oleh karena itu negara harus bisa menjadi penerima aspirasi rakyat dan mensejahterakan mereka (Rofiq, 1997: 24-25). Konsep kesejahteraan islam ini harus diukur dengan indikator yang sesuai dengan syari at islam agar memberikan pandangan dan tatanan yang efisien dan efektif. Salah satunya index 
pengukurannya adalah dengan penggunaan parameter maqashid syariah yang selalu ditautkan dengan kemashlahatan dalam berbagai studi ilmiah.

Maqashid syariah sebagai terminal tujuan hidup para muslim banyak dikembangkan pada era modern ini. Berawal dari konsep awal yang dikenalkan oleh penggagasnya Imam As-Syathibi dengan tiga maqashid utama bermetamorfosa menjadi pembahasan yang selalu dikaji terutama dalam penyusunan suatu konsep atau pencanangan kebijakan. Disamping Jaser Auda yang memang concern dalam bidang itu, terdapat salah satu ulama kontemporer yang memberikan klasifikasi khusus bagi konsep itu. Jamaluddin Athiyah menjelaskan bahwa maqashid syariah di era kontemporer kian berkembang dan lebih mengarah pada pengambilan kebijakan personal, keluarga, masyarakat, dan kemanusiaan. Ia juga membagi tiga prinsip dasar menjadi 24 bagian dengan kekuatan kepentingan sendiri-sendiri. Konsep tersebut sangat berkaitan dengan paham kenegaraan yang memang bermula dari keinginan individu yang berkonsi untuk membentuk suatu kekuasaan yang lebih besar. Artikel ini bertujuan untuk melakukan analisis mendalam terkait hubungan Negara Kesejahteraan dan maqashid syariah yang dikemukakan oleh Jamaluddin Athiyah.

\section{Landasan Teori}

\subsection{Kesejahteraan dan Negara Kesejahteraan}

Kesejahteraan menjadi tujuan utama kehidupan tiap individu dengan ukuran-ukuran yang berbeda sesuai dengan pandangan, agama, dan doktrin mereka masing-masing. Dalam dunia Internasional, indikator tersebut sering erujuk kepada pendapatan perkapita, panjangnya masa hidup dan tingkat pendidikan yang diraih (Goodin, 2015: 2). Namun dari sekian banyak alat ukur kesejahteraan yang dirumuskan tersebut dengan berbagai indikator di dalamnya, masih belum mampu merepresentasikan mengenai pemahaman kesejahteraan secara utuh, karena alat ukur tersebut hanya menyentuh dimensi material saja. Dalam alat ukur tersebut tidak ada dimensi spiritual yang dicantumkan, hal ini merupakan salah satu kelemahan dari alat ukur yang digunakan saat ini.

Konsep kesejahteraan sosial setidaknya dapat dibatasi menjadi sebuah bidang kajian akademik dan sebagai sebuah institusi sosial dalam sistem kenegaraan (Zhastrow, 2010: 3). NASW (National Association of Social Workers) sebuah organisasi pekerjaan sosial di Amerika, mendefinisikan social welfare sebagai sistem suatu negara yang berkenaan dengan program, keuntungan, dan pelayanan yang membantu masyarakat untuk menemukan kebutuhakan sosial, ekonomi, pendidikan, dan kesehatan yang menjadi dasar bagi kelangsungan hidup mereka (Zhastrow, 2010: 3). Pada akhirnya, Perbincangan mengenai kesejahteraan sosial akan mengkerucut pada dua poin utama, yaitu (1) apa yang didapatkan individu dari masyarakatnya, dan (2) seberapa jauh kebutuhan-kebutuhan mereka terpenuhi (Ashman, 2010: 6). 
Hingga saat ini, dikenal tiga bentuk model penyelenggaraan kesejahteraan sosial, yaitu residual welfare state yang memberikan pemerintah lebih sedikit kesempatan dalam intervensi publik sehingga sangat membuka pintu untuk swastanisasi (Ridho, 2017: 113), model institusional/ universalist welfare state yang menekankan negara untuk memberikan pelayanan publik yang maksimal dan komprehensif, dan social insurance walfare yang berupaya menempatkan social welfare (campur tangan negara dalam urusan kesejahteraan sosial) sebagai alat untuk meningkatkan produktifitas kelompok masyarakat penerima layanan kesejahteraan sosial dalam jangka panjang. Implementasi konsep ini dengan integrasi fungsi pemerintah - dunia usaha - buruh (Tribowo, 2006: 29).

Dalam pandangan Islam, 'sejahtera' bukan berarti 'yang kaya' namun 'yang ideal' yaitu keadaan dimana terjadi keseimbangan antara keadaan material dan spiritual yang diperoleh dari sumber-sumber daya yang ada (Donohue \& Esposito, 1989: 418). Semua hal yang diusahakan manusia, harus bertujuan untuk pemenuhan dua kebutuhan sentral itu agar terjadi keteraturan kehidupan personal sampai kepentingan lebih luas dalam bentuk kenegaraan.

Selanjutnya, definisi negara kesejahteraan adalah negara yang mengusahakan kesejahteraan rakyat dengan mengatasi anarki produksi dan krisis ekonomi, meningkatkan jaminan hidup warga dengan memberantas pengangguran (Dagun, 2000: 708). Di Inggris sistem welfare diawali dengan lahirnya UU Penanggulangan Kemiskinan (Poor Law- 1880-an). konsep welfare state dipahami sebagai alternatif terhadap the Poor Law yang kerap menimbulkan stigma, karena hanya ditujukan untuk memberi bantuan bagi orang-orang miskin (Mahfud MD, 2001: 64). Konsep tersebut menjadi counter bagi kemunculan welfare state sebagai lembaga perlindungan sosial bagi setiap orang dari adanya hak kewarganegaraan dan kewajiban pemerintah.

Konsep ini ditawarkan sebagai solusi dari kegagalan sistem kapitalisme dan sosialisme, dimana konsep ini berusaha menyampurkan kedua sistem dan menemukan titik temu yang melengkapi kelemahan keduanya (Chapra, 2000: 56). Kegagalan ini dikarenakan paham kapitalisme, kesejahteraan hanya meliputi pemenuhan kebutuhan dasar manusia bagi setiap individu, penghapusan kemiskinan, kesempatan kerja, dan distribusi pendapatan dan kekayaan secara adil di antara seluruh rakyat tanpa melibatkan ketenangan, kebahagiaan hidup, serta kedamaian. Akibatnya, paham kapitalisme ini lebih mengedepankan tujuan duniawi semata dan tidak memikirkan dari tujuan ukhrawi (Fuadi, 2015: 14). Sedangkan sistem sosialis, tidak mampu bertahan melawan arus inflasi, pengangguran dan utang luar negri yang terus meningkat dari tahun ke tahun (Chapra, 2000: 102-105). Dan sebenarnya tujuan lain sistem negara kesejahteraan ini adalah untuk mengurangi daya tarik sistem sosialis (Chapra, 2000: 113). 


\section{Metode Penelitian}

Penelitian ini menggunakan pendekatan kualitatif yang menghasilkan penemuan-penemuan yang tidak dapat dicapai dengan menggunakan produserproduser statistik atau metode lain dari kuantifikasi (pengukuran). Penelitian kualitatif bertujuan memahami realitas sosial, yaitu melihat suatu fenomena dari apa adanya, bukan fenomena yang seharusnya. Kualitatif disebut sebagai paradigma interaktif dan konstruktif, yang memandang realitas sosial sebagai sesuatu yang holistic dan utuh, kompleks, dinamis, penuh makna, dan hubungan gejala bersifat interaktif (Sugiyono, 2011). Pendekatan yang digunakan adalah pendekatan pustaka, yaitu melakukan kajian terhadap literatur seputar Negara kesejahteraan dan maqasid syariah. Selanjutnya analisis data menggunakan metode analisis isi (content analysis).

\section{Pembahasan}

\subsection{Konsep Negara Kesejahteraan Barat dan Islam}

Konsep dasar mengenai ke mengenai negara sejahtera didiawali dari pemikiran Sokrates yang menyatakan bahwa negara harus mewujudkan kesejahteraan penduduknya agar jiwa mereka merasa sebaik mungkin. Akibatnya seorang penguasa negara harus mempunyai pengertian tentang negara "yang baik" (Kansil, 2001: 133). Dikemudian hari, Plato, di dalam karyanya Republic, menggambarkan negara digambarkan dalam bentuk moralitas (Fadil, 2008: 171). Moralitas tersebut berasal dari individu-individu yang muncul disebabkan ketidakmampuan mereka untuk memenuhi kebutuhan yang beraneka ragam.Hal ini menyebabkan mereka harus bekerja sama melengkapikesejahteraanbersama dalam suatu kesatuan yang dinamakan negara (Soehino, 1980: 17). Hal ini adalah kontinuitas pemikiran Socrates yang dengan penekanan sisi moralnya sangat besar (Price, 1997: 366). Dalam pemahaman ini, pembentukan negara yang sejahtera harus diawali dengan perbaikan individu untuk mencapai suatu kelompok yang bersifat nasional bahkan internasional.

Pendapat itu dilengkapi oleh anggota "The Gang of Three" terakhir yaituAristoteles yang mengemukakan bahwa suatu negara akan terbentuk dari gabungan berbagai keluarga yang berkembang di masa selanjutnya menjadi kelompok yang besar. Kesejahteraan dalam kelompok besar tersebut akan tercapai bila terciptanya kesejahteraan individu sehingga bila mereka ingin bahagia maka ia harus bernegara dikarenakan manusia saling membutuhkan dalam pemenuhan kesejahteraan hidupnya.Negara tak lain terbentuk sebagai sebuah komposisi antara rakyat dan pengaturnya. Akan tetapi yang perlu diperhatikan adalah kekuasaan tertinggi terbentuk karena tujuan yang dimilikinya adalah untuk mensejahterakan seluruh warga negara, bukan individu-individu tertentu (Suhelmi, 2001: 45).

Marshall mendefinisikan negara kesejahteraan sebagai bagian dari sebuah masyarakat modern yang sejalan dengan ekonomi pasar kapitalis dan struktur 
politik demokratis.Sistem kesejahteraan negara sebagai kompensasi harus dibayar oleh kelas penguasa dan pekerja untuk menciptakan stabilitas sosial dan memelihara masyarakat kapitalis (Suharto, 2006: 5). Menurut Paul Spicker, Negara kesejahteraan adalah upaya untuk melepaskan diri dari stigma undangundang Miskin. Itu tidak dirancang untuk masyarakat miskin akan tetapi seharusnya menawarkan perlindungan sosial bagi semua orang, untuk mencegah orang dari menjadi miskin (Spicker, 2002: 6). Dalam sistem sosial itu peran negara lebih besar untuk mengalokasikan sebagian dana publik demi menjamin terpenuhinya kebutuhan dasar warganya (Suharto, 2005: 50).

Suatu negara bisa digolongkan sebagai negara kesejahteraan apabila terdapat empat pilar utama, yaitu: 1) social citizenship; 2) full democracy; 3) modern industrian relation systems; 4) rightsto education and the expansion of modern mass education systems. Keempat pilar tersebut harus diupayakan terdapat dalam negara kesejahteraan karena negara wajib memperlakukan penerapan kebijakan sosial sebagai penganugerahan hak-hak sosial kepada warganya yang berdasarkan atas basis kewarganegaraan dan bukan atas dasar kinerja atau kelas sosial (Bahagijo, 2006: 9). Pematangan konsep negara kesejahteraan terjadi pada periode akhir 1960 dan awal 1970-an. pada periode tersebut negara-negara eropa banyak mengadopsi berbagai progam jaminan sosial baru seperti program pensiun, program jaminan orang cacat, dan santuanan pagi pengangguran (Bahagijo, 2006: 28).

Perkembangan globalisasi ekonomi yang mengutamakan pasar bebas pada abad ke-21 telah mengubah peta konsep dan struktur konsep kenegaraan sebelumnya (Petras \& Veltmeyer, 2002: 37). Akhirnya batas dan kekuatan negara kesejahteraan. sebuah konsekuensi logis dari kecenderungan internasional dan memunculkan berbagai kritik mengenai pendekatan teori ini dalam pembangunan negara sehingga terdapat anggapan bahwa negara kesejahteraan telah mati (welfare stae has gone away and died).

Dalam Islam, konsep Negara kesejahteraan dikemukakan oleh al-Mawardi berpendapat bahwa Allah yang menciptakan kita supaya tidak sanggup memenuhi kebutuhan kita seorang diri tanpa bantuan dari orang lain, agar kita selalu sadar bahwa Dia-lah pencipta kita dan pemberi rezeki dan memberikan pertolongannya kepada kita. Ia mengemukakan bahwa negara itu memerlukan enam sendi utama untuk merealisasikan kesejahteraan rakyatnya yaitu dengan: Pertama, Agama yang dihayatai. Kedua, Penguasa yang beribawa. Ketiga, Keadilan yang menyeluruh. Keempat, Keamanan yang merata. Kelima, Kesuburan tanah yang berkesinambungan dan keenam, harapan akan kelangsungan hidup (Soehino, 1980: 60-61).

Al-Ghazali beranggapan bahwa kebutuhan manusia akan keturunan demi kelangsungan hidup manusiamungkin hanya dilakukan melalui pergaulan laki-laki dan perempuan serta keluarga. Mereka juga harus saling membantu dalam menyediakan bahan makanan, pakaian, dan pendidikan anak. Untuk itu semua 
diperlukan kerja sama dan saling membantu antara sesama manusia untuk terciptanya kesejahteraan bersama, dari sinilah muncul teori asal mula timbulnya negara dan kesejahteraannya (Soehino, 1980: 60-61).

Al-Farabi beranggapan bahwa suatu negara yang berketuhanan harus bertujuan kebahagian bersama, materil dan spritual dibawah pimpinan seorang Presiden dan atau bersama wakil-wakinya yang bersifat kenabian. Negara itu didukung oleh rakyatnya yang bersifat gotong royong, kolektif dan kooperatif di dalam cara berfikirnya dan cara bekerjanya (Mahmuda, 2017: 294). Negara tersebut dicita-citakan akan mengatur dunia Internasional dengan satu lembaga yang bersifat Universal dan untuk mencontohkan suatu negara utama (al-Madinah al-Fadilah) dimana negaranya dipimpin oleh seorang filosof yang suci jiwanya sehingga dapat mendekati sifat seorang Nabi (Amien, 1945: 103).

Peran kesejahteraan dengan 'regulasi yang tepat' dan pengeluaran untuk tujuan-tujuan kesejahteraan juga dimasukkan ke dalam konsep ini. Namun, yang terjadi justru pengeluaran untuk tujuan kesejahteraan yang terlalu besar tanpa dibarengi dengan pengurangan pengeluaran sektor swasta dan pemerintah pada bidang-bidang lainnya, dan menimbulkan klaim berlebihan pada sumbersumber daya dan menjadi bumerang bagi konsep ini (Chapra, 2000: 60-61).

Selanjutnya Chapra (2000: 60-61) menegaskan bahwa negara Islam dalam mewujudkan negara sejahtera adalah menciptakan standar hidup yang layak bagi rakyatnya dan membantu mereka yang tidak mampu mencukupi kebutuhan hidupnya. Namun, konsepsi Islam dalam pemeratan pendapatan dan distribusi kekayaan tidak menyamaratakan kepemilikan bagi semua orang, tetapi mengakui perbedaan yang dibatasi oleh hak-hak kaum miskin dengan zakat untuk mewujudkan keadilan. Untuk melaksanakan kewajiban tersebut, maka negara memerlukan adanya sumber-sumber penghasilan. Sumber-sumber tersebut antara lain: zakat, penghasilan dari sumber alam, pemungutan pajak dan pinjaman (Donohue \& Esposito, 411). Oleh karena itu, negara Islam dapat dikatakan menjadi negara yang sejahtera atau ideal bilamana martabat batin dan moral masyarakat meningkat, kewajiban-kewajiban masyarakat sebagai khalifah di bumi terhadap sumber daya alam telah ditunaikan, dan tegaknya keadilan serta lenyapnya penindasan. Negara Sejahtera menurut Islam, bukanlah negara kapitalis ataupun sosialis, akan tetapi negara dengan konsep Islam dan kehidupan Islami (Donohue \& Esposito, 418).

Dalam merealisasikan nilai-nilai spritual Islam ke dalam setiap individu dan masyarakat, negara haruslah berusaha dalam tiga pedoman utama. Pertama, negara haruslah mengembangkan kondisi-kondisi yang kondusif dalam penciptaan keadaan rumah yang menanamkan kepedulian dan kesetiaan terhadap moral-moral Islam pada generasi selanjutnya. Kedua, negara Islam haruslah membentuk sistem pendidikan dalam bentuk yang Islami sehingga institusi pendidikan dapat menghasilkan generasi yang memiliki idealisme Islam. Dan terakhir, negara seharusnya menekankan norma-norma dan nilai-nilai Islam 
tersebut yang sesuai dengan aturan perundangan dan membentuk aturan yang dapat menghukum bagi setiap pelanggaran sehingga mereka dapat berfungsi sebagai pencegah dalam setiap pelanggaran (Chapra, 1979: 9-10). pertama, berusaha melakukan pengentasan kemiskinan dan pemenuhan semua kebutuhan dasar manusia; kedua, pemanfaatan secara penuh dan efisien terhadap seluruh sumber daya manusia dan alam untuk mencapai tingkat pertumbuhan ekonomi yang optimum dan meningkatkan standar hidup manusia; dan yang terakhir, menghindari kondisi-kondisi yang membangkitkan pengurangan atau kelebihan permintaan dan mengarahkan kepada peningkatan penggangguran atau inflasi.Hal-hal yang harus dicanangakn adalah dengan: Stabilitas nilai uang riil, Keadilan Sosial dan Ekonomi, Hukum dan Tata Tertib, Perlindungan Sosial dan Keadilan Distribusi, Penyediaan Sumber Daya.

Konsep mengenai Negara Kesejahteraan Islami dapat menjawab tantangan dunia dengan ajaran normatif yang membalut aspek sosial dan ekonomi dan politik yang ada. Islam juga berfungsi sebagai pandangan hidup sehingga memiliki konsep ketatanegaraan yang berfungsi untuk merealisasikan kesejahteran yang sinergis antara kepentingan duniawi dan ukhrowi. Karena konsepnya begitu komprehensif, negara kesejahteraan dalam Islam bertujuan mencapai kesejahteraan umat manusia secara menyeluruh, sedangkan kesejahteraan ekonomi hanya sebagaian daripada bagian lain yang berupa spiritual dan politik islam yang tak kalah penting (Cahyo, 2009: 66-68). Islam mengambil posisi tengah dengan kekuatan lebih besar karena berusaha menggabungkan paksaan negara dengan kekuatan dorongan pada diri manusia secara suka rela (Naqvi, 2003: 116).

\subsection{Relevansi Negara Kesejahteraan dan Maqashid Syariah}

Secara terminologi, maqashid syarîah dapat diartikan sebagai nilai dan makna yang dijadikan tujuan dan hendak direalisasikan oleh pembuat Syariah (Allah swt) dibalik pembuatan Syariat dan hukum, yang diteliti oleh para ulama mujtahid dari teks-teks Syariah (Auda, 2007: 15). Maqashid ini hanya ada tiga yaitu dlaruriyat, hajiyat, tahsiniyat. Daruriyat harus ada untuk menjaga kemaslahatan dunia dan akhirat. Jika hal ini tidak ada maka akan terjadi kerusakan di dunia dan akhirat. Kadar kerusakan yang ditimbulkan adalah sejauh mana daruriyat tersebut hilang. Maqashid al- dlarûriyât ini ada lima yaitu: menjaga Agama, menjaga jiwa, menjaga keturunan, menjaga harta, menjaga akal. Maqashid hajiyat adalah untuk menghilangkan kesusahan dari kehidupan mukallaf. Sedangkan Maqashid tahsiniyat adalah untuk menyempurnakan kedua Maqashid sebelumnya, yang meliputi kesempurnaan adat kebiasaan, dan akhlak yang mulia (Raisuni, 1992: 117).

Jamaluddin Athiyyah melakukan metamorfosa konsep maqashid syari`ah yang terkenal dengan lima maqashid dharuriyah nya yang kemudian dijabarkan menjadi empat divisi yang lebih spesifik. Maqashid syariah tersebut dilihat 
melalui kebutuhan individu sampai kelompok yang lebih besar. Maka dengan penjabaran yang lebih luas ini sangat mendukung konsep kenegaraan beserta kewajiban sebagai pusat penyedia kesejahteraan dimana dimulai dari pembentukan peradaban rumah tangga hingga berbentuk koloni yang lebih besar yang sering disebut sebagai negara. Pembagian tersebut meliputi jaminan lingkup individu, jaminan lingkup keluarga, jaminan lingkup masyarakat, dan jaminan lingkup kemanusiaan.

Reformasi klasifikasi Maqashid Syariah tersebut dapat dibagi menjadi beberapa hal berikut:

1) Ranah Individu yang meliputi: (a) Perlindungan Jiwa Personal, (b) Perlindungan Akal, (c) Perlindungan Menjalankan Agama, (d) Perlindungan Kehormatan, (e) Perlindungan Harta Individu.

2) Ranah Keluarga meliputi: (a) Pengaturan Hubungan Antar Individu, (b) Perlindungan Keturunan (Ras), (c) Kenyamanan, (d) Perlindungan Keturuanan, (e) Pendidikan Keagamaan, (f) Penguatan Hubungan Antar Anggota Keluarga, (g) Perlindungan Keuangan Keluarga.

3) Ranah Masyarakat meliputi: (a) Penguatan Hubungan Kemasyarakatan, (b) Keamanan, (c) Keadilan Sosial, (d) Pendidikan Agama dan Akhlak, (e) Tolong-menolong/Asuransi, (f) Penyebaran Ilmu, (g) Keadilan Harta Publik.

4) Ranah Kemanusiaan meliputi: (a) Upaya Saling Mengenal dan Mengetahui, (b) Penetapan Pemimpin (Khalifah), (c) Kedamaian Internasional, (d) Pemenuhan Hak-Hak Manusia, (e) Penyebaran Dakwah Islamiyah.

Dibawah ini adalah diagram maqashid syari`ah yang diajukan oleh Jamaluddin Athiyah yang direalisasikan dengan konsep kenegaraan. Lingkaran pertama menandakan ruang lingkup pemberdayaan individu. Lingkarna kedua menandakan rung lingkup keluarga. Lingkaran ketiga yang semakin meluas bermakna cakupan pemberdayaan maqashid yang semakin lebar. Garis paling luar berarti kemanusiaan yang berdiri mencakup semua ruang lingkup. Warna merah menandakan maqashid dharuriyah yang memang menjadi kebutuhan urgen bagi Muslim. Sedangkan warna kuning sebagai simbol kebutuhan tambahan atau maqashid hajiyah yang bertugas menjadi pelengkap. 
Gambar 1.1

Maqashid Syariah dan Relevansinya dengan Negara Kesejahteraan

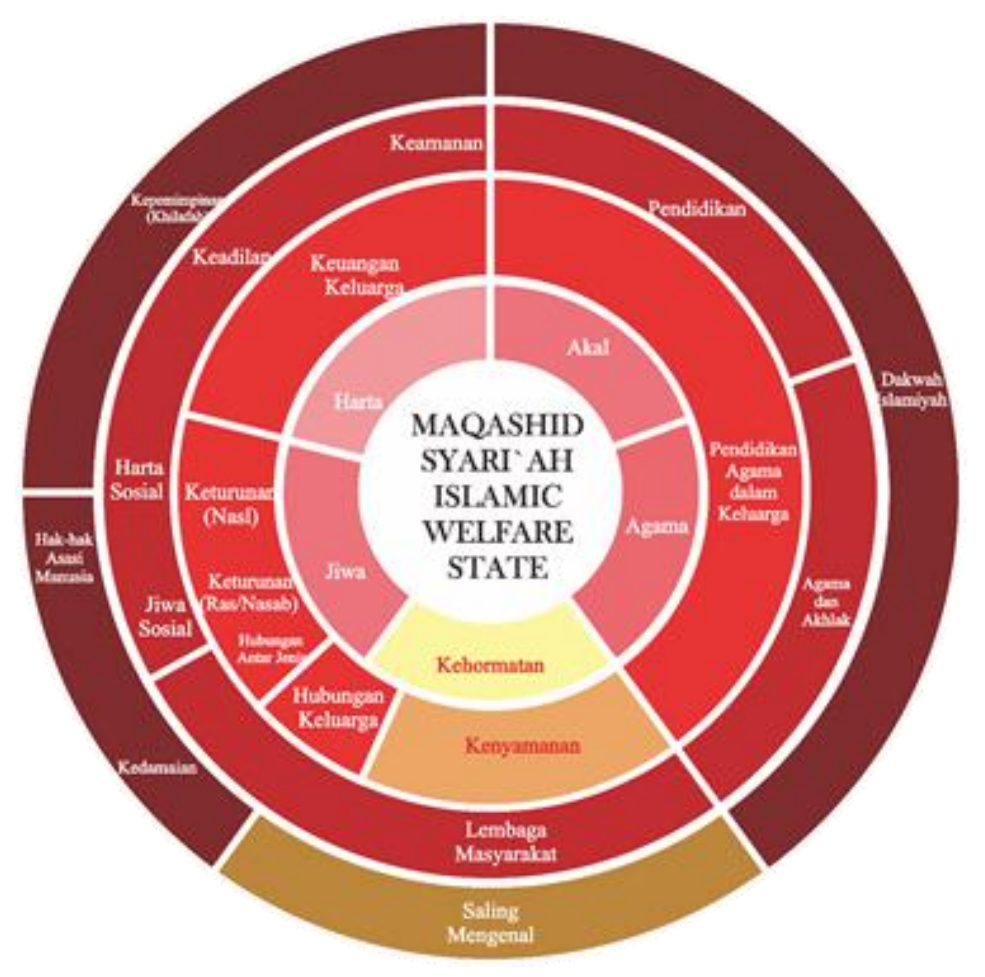

\subsubsection{Dimensi Individu}

Dalam menjamin jiwa personal, negara diharuskan memperketat keamanan untuk menghindari potensi pertikaian. Jaminan terjaganya nyawa tersebut dari semua hal yang dapat merusak anggota badannya bahkan sampai membunuh jiwanya dengan melakukan pembayaran denda (diyah) kepada korban atau keluarganya melalui penegakan hukum qishash (Athiyyah, 1423: 142-143).

Selanjutnya kebutuhan dasar yang dibutuhkan oleh jasad harus diupayakan oleh pemerintah seperti pangan, papan, sandang, listrik, penyembuhan penyakit, dan rasa bahaya lainnya seperti kebakaran dan tenggelam. Setelah semua perangkat tersebut terlengkapi, kebebasan individu dan kehormatan manusia harus diberikan dengan batasan-batasan tertentu (al-Khoubah, 1978: 130-135).Negara harus menjaga akal, otak, panca indra, dan sistem saraf agar terhindar dari semua pemicu kerusakannya dari hal yang memabukkan dan membahayakan. Serta berupaya dalam menyembuhkan penyakit-penyakit jiwa dan saraf (Al-Alim, 1991: 366-392). Selanjutnya Pemerintah wajib mengedepankan pendidikan dan wawasan yang tetap berhubungan dengan aqidah dan ibadah (al-Qardhawi, 1999: 187-197). Wawasan tersebut harus dilengkapi dengan pelatihan ketrampilan dan kemampuan untuk digunakan sebagai modal dalam dunia kerja (Ismail, 1993: 104-153). Berbagai macam riset pun dibutuhkan agar membuat otak bekerja untuk 
menganalisa data dengan mentadaburi semua yang telah diciptakan oleh Allah. Hal seperti ini termasuk ibadah a qliyah yang hanya sebatas fardhu kifayah bagi suatu kelompok.Kemudian, Rakyat juga diupayakan sebisa mungkin agar terhindar dari moral-moral yang tercela yang merusak sistem kerja otak seperti sombong, mengikuti hawa nafsu, dan perkelahian sehingga mereka dapat menggunakan akal sebagai fitrah (Ismail, 1993: 46). Pemerintah selayaknya menjamin seseorang untuk dapat menegakkan akidah yang kuat dan kuat dari faktor-faktor perusaknya. Menghindari dosa-dosa besar yang berhubungan dengan akidah (al-Qardhawi, 1997: 65-69). Dengan adanya jaminan tersebut, seseorang akan dapat mendirikan syiar-syiar ibadah wajib dan menjalankan dasar akhlak islami lainnya seperti ikhlas, sabar, dan lainnya (al-Qardhawi, 1997: 83-85).

Kehormatan seseorang akan terjaga dengan menjauhkan perilaku personal akan permusuhan dengan menjaga pembicaraan dengan menghindari tuduhan palsu (terutama zina) dan gosib (Athiyyah, 1423: 146). Jamaluddin Athiyyah memiliki pemikiran yang sama dengan ibnu aasyur yang menyatakan jaminan kehormatan individu berada di tingkat kebutuhan sekunder (al-Khoubah, 1978: 81-82). Perangkat pemerintah wajib mencanangkan kebijakan transaksi dan pekerjaan seperti hukum kepemilikan, hukum waris, dan pemanfaatan lahan kosong untuk membuka lapangan pekerjaan yang halal untuk menjga keamanan keuangan personal rakyatnya (Athiyyah, 1423: 147). Kemudian kebijakan tersebut akan diikuti dengan himbaun berinfaq dan menghindari tabdzir serta hukuman hudud bagi pelaku kejahatan yang berhubungan dengan kepemilikan harta.

\subsubsection{Dimensi Keluarga}

Hubungan antar jenis yang tidak teratur akan menyebabkan ketidakteraturan silsilah keluarga. Oleh karena itu negara berkewajiban memberantas perzinahan dan segala hal yang menjadi pemicunya. Selanjutnya sebagai konsekuansi dari kebijakan tersebut, pernikahan harus dipermudah dan digenjarkan sehingga rakyat dapat terhindar dari fitnah pergaulan antar jenis tersebut (Athiyyah, 1423: 149). Bahkan untuk kelanjutnanya, negara harus menentukan persyaratan-persyaratan tertentu yang harus ditempuh jika ada yang ingin melakukan praktek Poligami atau perceraian yang merupakan kebutuhan tersier keluarga tersebut (al-Husni, 1995: 210).

Keturunan yang dimaksud disini berhubungan dengan garis keturunan keatas yang menautkan nama besar ras dan keluarga. Suatu ras akan mengalami kepunahan jika mereka melakukan praktek reproduksi dengan cara terlarang seperti LGBT. Oleh karena itu, untuk menambah jumlah populasi ras tersebut negara islam harus menjaga angka bahkan jika dibutuhkan perlu meringankan proses kelahiran keluarga rakyatnya. Kebijakan mengenai pelarangan praktek aborsi juga harus dicanangkan untuk menjamin keberlangsungan ras ini (Athiyyah, 1423: 150). 
Kasih sayang antar keluarga selayaknya terus berjalan lancar terutama suami-istri. Disini peran negara dibutuhkan untuk mencanangkan kebijkan dan tindakan yang berhubungan dengan kenyamanan, cinta, dan kasih sayang dalam berkeluarga.Keturunan dalam skala ini berhubungan dengan keluarga garis kebawah yang meliputi anak. Untuk melakukan jaminan keturunan keluarga tertentu, negara harus mencanangkan larangan praktek zina, aborsi, dan bayi tabung. kebijakan mengenai masa iddah juga diperlukan untuk menjaga kelangsungan hidup sang calon bayi (Athiyyah, 1423: 151-152).

Negara harus mencanangkan kebijakan untuk kepala keluarga sebagai penanggung jawab utama agama anggota keluarganya dengan mengjari anak dan istrinya mengenai agama. Selanjutnya, negara wajib memberlakukan peraturan mengenai hubungan, hak, dan kewajiban antar suami-istri, orangtua-anak, tetangga, kerabat, dan lainnya.Pemerintah dengan segala kekuasaannya selayaknya mengatur ketentuan mahar, pemberian berbagai macam nafkah, warisan, wakaf keluarga, denda, dan peraturan lain yang berkenaan dengan harta.

\subsubsection{Dimensi Masyarakat (Umat)}

Dalam berjalannya suatu kesatuan masyarakat, pemerintah layaknya mendirikan berbagai macam lembaga kemasyarakatan demi tercukupinya kebutuhan masyarakat yang berupa baitul maal, masjid, dan lembaga wakaf (Athiyyah, 1423: 155). Hal ini digunakan untuk mereduksi kapitalisme dan egoisme kehidupan kemasyarakatan. Penguatan persatuan umat dengan satu aqidah, syari ah, dan bahasa harus digaungkan oleh pemerintah (Athiyyah, 1423: 156). Hal tersebut tidak terlepas dari pemilihan pemimpinkhusus atas umat islam yang kompeten sebagai tonggal awal pelaksanaannya. Adanya pemimpin tersebut tidak mutlak dalam perencanaan program negara. Ia dengan Pemerintah lainnya, harus bermusyawarah untuk mencapai kebijakan yang benar dan baik.

Keamanan masyarakat dijamin dari segi internal dan eksternal. Mereka menginginkan keamanan tersebut demi kelangsungan seluruh aktivitas religi dan sosial mereka dengan lancar. Untuk kebutuhan tersebut, pemerintah wajib mempersipakan kekuatan militer yang kuat agar dapat mencegah dan menanggulangi problematika tersebut. Keamanan tersebut akan menghasilkan keadilan yang dibutuhkan sebagai olehindividu, keluarga, masyarakat, pergaulan dengan orang lain, dalam penentuan keputusan hukum, dan dalam disiplin hukum (al-Fasi, 1993: 45-56). Pengamalan agama dalam kemasyarakatan harus mendapat dukungan dari negara. Pemerintah wajib memudahkan dan memberi himbauan pada masyarakat untuk memenuhi kebutuhan agama seperti shalat berjama'ah (Athiyyah, 1423: 160). Pelaksanaan kegiatan-kegiatan keagamaan tersebut akan memepengaruhi pada akhlak yang berupa kejujuran dan amanah.

Masyarakat bertanggung jawab akan anggota kemasyarakatannya itu sendiri. Kepengasuhan, Zakat, Wakaf, dan donasi lainnya adalah bentuk nyata bahwa masyarakat saling membutuhkan dan mengerti bahwa mereka tidak dapat hidup 
sendiri (Athiyyah, 1423: 160). Negara sebagai regulator memiliki kewajiban untuk mengeluarkan kewenangan dan ketentuan dasar untuk mendorong kepedulian sosial masyarakatnya. Lembaga kemasyarakatan tersebut akan mendukung program pendidikan dan pengajaran masyarakat pada fase yang labih jauh. Dengan ilmu agama dan kompetensi profesi, masyarakat akan dapat menjadi umat yang produktif. Mereka tidak hanya termotivasi untuk mendapatkan keuntungan pribadi, akan tetapi akan menciptakan keadilan sosio-ekonomi melalui berbagai macam bentuk filantropi.

\section{Kesimpulan}

Berdasarkan pemaparan di atas dapat disimpulkan bahwa, manusia senantiasa memerlukan kelompok agar dapat menjalankan kehidupan mereka secara lancar. Kelompok yang diinginkan manusia tersebut berkembang dan membesar dari awal mulanya menjadi suatu negara dengan undang-undang dan kewajiban yang telah ditetapkan bersama. Beberapa negara tersebut tidak berjalan secara seimbang dikarenakan hegemoni kapilatis yang terus melebarkan jurang dualisme antar golongan. Kemiskinan kian bertambah di ranah kaum proletar akibat kebebasan pasar yang ada di negara tersebut. Pada akhirnya terjadi revolusi yang mengancam kekayaan kaum borjuis dari permintaan kaum bawah yang terus menginginkan persamaan strata pada idealisme sosialisme.

Maka dunia barat menjembataninya dengan memberikan sedikit kekayan mereka lewat program filantropi dan publik dengan sedikit tekanan yang dibantu oleh negara dalam bentuk Negara Kesejahteraan. Disini, negara wajib menjamin hak-hak prinsipil warga negara dengan berbagai macam bentuk jaminan sosial dengan menyesuaikan kebutuhan mereka. Pada akhirnya konsep ini goyah, karena dirasa tidak efektif pada pengentasan kemiskinan.

Dalam Islam, negara wajib memenuhi hak-hak masyarakatnya secara adil. Kepemerintahan dalam Islam bersifat amanah yang akan dipertanggung jawabkan pada hari akhir. Hal ini menandakan pemerintah akan menjalankan tugas sebaik mungkin jika tidak ingin diberatkan di akhirat. Dalam permasalahan keadilan sosial dan ekonomi, islam menetapkan berbagai kewajiban finansial bagi muslim dan non muslim yang akan dibagikan sesuai dengan proporsi yang telah dikembangkan dari ketentuan dasar syariah. Jamaluddin Athiyah, seorang ulama maqasid syariah melakukan formulasi maqasid sesuai dengan ranah kemampuan untuk mengimplementasikannya. Ia membagi tiga prinsip dasar maqasid syariah dalam ranah individu, keluarga, masyarakat, dan kemanusiaan. Pembagian tersebut sangat berpengaruh pada skala prioritas realisasi progam Negara Kesejahteraan Islami yang menginginkan kemaslahatan umum. Konsep itu dilandasi pemahaman bahwa tiga prinsip dasar maqasid syariah tidak bisa terpenuhi hanya dengan kekuatan individu melainkan dengan bantuan keterikatan negara. 


\section{Daftar Pustaka}

A.W Price, Plato: Ethics And Politics, C.C. W. Taylor (Ed). Routledge History Of Philosophy: From The Beginning To Plato (London: Routledge, 1997)

al-Alim, Yusuf Haamid. al-Maqasid al-Aamah li As-Syari`ah Al-Islamiyah, (AlMa`had Al-`Aalamiy li al-Fikri al-Islmaiy, 1991)

al-Fasi, 'Ilal. Maqashid Al-Syaria`ah Al-Islamiyah wa Makarimuha, (Dar AlGharb al-Islamiy, 1993)

al-Husni, Ismail. Nadzariyah Al-Maqashid `Inda Al-Imam Kuhammad Al-Thahir Ibnu `Aasyuur, (Al-Ma`had Al-`Aalamiy Li AL-Fikri Al-Islamiy, 1995)

Al-Khoubah, Muhammad Al-Habib Ibn. Muhammad Al-Thahir Ibn Aasyur wa Kitabuhu Maqashid Al-Syari'ah Al-Islamiyah, (Tunis: Al-Syirkah AlTunisiyah, 1978)

al-Qardhawi, Yusuf. Kaifa Nata`ammalu Ma`a Al-Qur`an Al-Adziim, (AlDauhah: Jaami`ah Qathr, 1997)

al-Qardhawi, Yusuf. Taisir Al-Fiqh (Fiqh Al-`Ilm), (Kairo: Maktabah Wahbah, 1999)

al-Raisuni, Ahmad. Nadariyât al- Maqāșid „Inda alImâm al-Shâthibi, (Beirut: Muassasah al-Jami`ah, 1992)

Amien, Ostman. Syahsyiat Wa Mazhab Falsafiah, (Cairo:Darru Al-Kutubi AlArabiyah, 1945)

Aristotle, Politic (Book III). P.V

Athiyyah, Jamaluddin. Nahwa Taf iil Maqashid Al-Syari`ah, (Damaskus: Daar Al-Fikr, 1423 H.)

Auda, Jasser. Fiqh al- Maqāṣid Ināṭat al-Ahkām bi Maqāṣidihā, (Herndon: IIIT, 2007)

Bahagijo, Sugeng. et.al,. Mimpi Negara Kesejahteraan, (Jakarta: LP3ES, 2006)

C.S.T. Kansil, Ilmu Negara Umum Dan Indonesia, ( Jakarta: Pt: Pradnya Paramita, 2001)

Cahyo, Eko Nur. Tatanan Sosial Islami: Kajian Pemikiran M.Abdul Mannan dalam "Islamic Economics, Theory and Practice", Jurnal Literasi, Edisi 2, Tahun 1, Juni 2009

Chapra, M. Umer Islam Dan Tantangan Ekonomi, Edisi Terjamahan Dari Islam And The Economic Challenge, (Jakarta: Gema Insani Press Atas Kerjasama Dengan Tazkia Institute, 2000)

Chapra, Umer. The Islamic Welfare State and Its Role in The Economy, (Leicester: The Islamic Foundation, 1979)

Dagun, Save M. Kamus Besar Ilmu Pengetahuan, (Jakarta: Lpkn, 2000)

Donohue, John J. \& Esposito, John. L. Islam Pembaharuan:Ensiklopedi Masalah-Masalah, Cet. Ii, Diterjemahkan Dari Islam In Transition: Muslim Perspective, Oleh Machnun Husein, Yogyakarta, (Jakarta: Cv. Rajawali, 1989)

Fadil, Muhammad. Gagasan Dasar Mengenai Etika dan Negara Menurut Plato (Sebuah pengenalan awal filsafat politik klasik), Jurnal Lppm : Paradigma Vol 9, No 01 (2008): Paradigma : Desember 2008

Fuadi, Ariza Negara Kesejahteraan (Welfare State) Dalam Pandangan Islam Dan Kapitalisme, Jurnal Ekonomi Syariah Indonesia, Vol. V, No.1, Juni 2015 
Goodin, E. Robert. The Real Worlds of Welfare Capitalism, dalam: H. Satria Azizy, Mendudukkan Kembali Makna Kesejahteraan Dalam Islam, (Ponorogo: Centre for Islamic and Occidental Studies (CIOS), 2015)

Ismail, Fathimah. Al-Qur’an wa Al-Nadzr Al-Aqliy, (Al-Ma`had Al-`Aalamiy li Al-Fikr Al-Islamiy, 1993)

Kirst-Ashman, Karen K. Introduction To Social Work And Social Welfare, Critical Thinking Perspectives, 3rd Edition,(USA: Brooks, 2010)

Mahfud MD, Moh. Dasar dan Struktur Ketatanegaraan Indonesia (Edisi Revisi), (Jakarta: Renaka Cipta, 2001)

Mahmuda, Konsep Negara Ideal/ Utama (Al-Maḍinah Al-Fāḍilah) Menurut AlFarabi, Al-Lubb, Vol. 2, No. 2, 2017

Naqvi, Syed Nawab Haider. Menggagas Ilmu Ekonomi Islam, (Yogyakarta:Pustaka Pelajar, 2003)

Petras, James dan Veltmeyer, Henry. Imperialisme Abad 21, (Yogyakarta: Kreasi Wacana, 2002)

Ridho, Miftahur. Pandangan Islam Tentang Kesejahteraan Sosial Bagi Kelompok Penyandang Disabilitas, Jurnal Al-Bayan, Vol. 23. No. 1 Januari - Juli 2017

Rofiq, Ainur. Ed., Etika Ekonomi Politik: Elemen-Elemen Strategis Pembanguan Masyarakat Islam, (Surabaya: Rislah Gusti, 1997)

Soehino, Ilmu Negara, (Yogyakarta, Liberty, 1980), H.17

Spicker, Paul. Poverty and the Welfare State: Dispelling the Myths, (London: Catalyst, 2002)

Suharto, Edi. Makalah disampaikan pada Seminar, Mengkaji Ulang Relevansi Welfare State dan Terobosan melalui DesentralisasiOtonomi di Indonesia, Institute for Research and Empowerment (IRE) Yogyakarta dan Perkumpulan Prakarsa Jakarta, bertempat di Wisma MM Universitas Gadjah Mada, Yogyakarta 25 Juli 2006

Suharto, Edi. Membangun Masyarakat Memberdayakan Rakyat: Kajian Strategis Pembangunan Kesejahteraan Sosial dan Pekerjaan Sosial,(Bandung: Refika Aditama, 2005)

Suhelmi, Ahmad. Pemikiran Politik Barat, (Jakarta: Gramedia Pustaka Utama, 2001).

The Legatum Institute Foundation, The Legatum Prosperity Index, (London: The Legatum Institute Foundation, 2016)

Tribowo, Darmawan dan Bahagijo, Sugeng, mimpi negara kesejahteraan, (Jakarta: Pustaka LP3ES, 2006)

Zhastrow, Chales. Introduction To Social Work And Social Welfare, 10th Edition, (Belmont: Cengage Learning, 2010)

http://www. http://hdr.undp.org/en/data.

http://www.who.int/about/en/.

http://www.who.int/gho/mental_health/suicide_rates/en/ 